\title{
Globalization, nation-state and catching up
}

\section{LUIZ CARLOS BRESSER-PEREIRA*}

Globalization and nation-states are not in contradiction, since globalization is the present stage of capitalist development, and the nation-state is the territorial political unit that organizes the space and population in the capitalist system. Since the 1980s, Global Capitalism constitutes the economic system characterized by the opening of all national markets and a fierce competition between nation-states. Developing countries tend to catch up, while rich countries try to neutralize such competitive effort, using globalism as an ideology, and conventional orthodoxy as a strategy. Middle-income countries that are catching up in the realm of globalization are the ones that count with a national development strategy. This is broadly the case of the dynamic Asian countries. In contrast, Latin American countries have no longer their own strategy, and grow less. To add data to the argument, the author conducts an econometric test comparing these two groups of countries, and three variables: the rate of investment, the current account deficit or surplus that would indicate or not a competitive exchange rate, and public deficit.

Keywords: globalization; globalism; nation-state; nationalism; financial globalization.

JEL Classification: F31; F32; F4.

Unlike conventional wisdom, globalization and nation-states are phenomena that do not contradict each other, but are rather part of the same universe of contemporary capitalism. Soon after the collapse of communism in the early 1990s, globalization was presented as an indication of American hegemony and of the affirmation of a single path to economic development - the neo-liberal path of

\footnotetext{
*Professor of Economics at Fundação Getulio Vargas, São Paulo. E-mail: lcbresser@uol.com.br. Submitted: May 2007; Accepted: August 2007.
} 
the Washington Consensus or of conventional orthodoxy. ${ }^{1}$ On the opposite side, economists and politicians identified with the new hegemony said that globalization would benefit everyone. Martin Wolf (2004: 4) summarized this view: "The failure of our world is not that there is too much globalization but that there is too little". In the same line, the World Bank (2002) published a report in which it stressed globalization's success in promoting the reduction of poverty and the catching up. In order to demonstrate its point of view, it divided nation-states into three groups - rich ones, more globalized developing ones, and less globalized developing ones - showing that, in the 1990s, whereas the per capita growth rate of rich countries increased nearly $2 \%$, and the growth rate of more globalized developing countries (corresponding to nearly three billion inhabitants) grew at rates around $5 \%$, in less globalized countries the rates were negative, around $1 \%$ per annum. The report also regards both trade and financial globalization as positive, although, as to the second one it is forced to acknowledge an increase in financial crises. This is where my key disagreement lies. Whereas I regard trade globalization as a competitive opportunity for middle-income countries - an opportunity to catching $u p$ - I understand that financial globalization is usually disastrous for developing countries, since it makes them unable to neutralize the tendency to the overvaluation of the exchange rate.

It is not surprising that 'more globalized' countries are being successful, since they are also 'more capitalist' countries - they are countries that have already completed their capitalist revolution. Differently from poor countries, these are middle-income countries that already have business and technical capabilities combined with cheap labor - what gives them an advantage in international competition. However, among these countries we must distinguish the fast from the low growing countries - the ones that have from the ones that have not its own national development strategy. In this paper, my main purpose is to discuss why trade globalization is an opportunity from which many middle income countries are profiting, while other are not. As we will see, while commercial globalization is an opportunity for middle income countries, financial globalization is a threat. Trade liberalization is damaging only to poor countries that are still trying to begin their process of industrialization - that have infant industries.

Both trade and financial globalizations tend to move together, and there will always be economists ready to state that it is impossible to separate one from another, but experience shows that many countries, particularly the Asian ones, have been able to make this separation. The condition that makes trade globalization an opportunity rather than a threat to developing countries is their ability to

\footnotetext{
${ }^{1}$ I have no sympathy for orthodoxy, which is a way of renouncing our thinking faculty, but reject the adjective heterodox that often characterizes economists that renounced to be dominant, or to achieve the implementation of his ideas and policies and reserve for themselves the role of eternal minority opposition. A good economist is neither orthodox nor heterodox but pragmatic: he can make good economic policy based on an open, modest theory that forces him to constantly consider and decide under conditions of uncertainty.
} 
neutralize the negative aspects of financial globalization, principally the tendency to the overvaluation of the exchange rate. This tendency results primarily from two structural characteristics: the Dutch disease that affects practically all developing countries, and the attraction that the higher profit and interest rates usually prevailing in those countries have on foreign capital (Bresser-Pereira, 2008). The Dutch disease is a particularly serious market failure because it appreciates the exchange rate without affecting the current account balance, so that overvaluation is kept indefinitely. On its hand, the structural attraction of foreign savings also appreciates the national currency, but this would not be so bad if these foreign capitals would increase the country's rate of investment. Yet, as I have been arguing for some time, this is not true; before the growth with foreign savings policy causes excessive foreign indebtedness and balance of payment crises, it promotes the substitution of foreign for domestic savings, and the country gets indebted but does not grow (Bresser-Perereira and Nakano, 2003; Bresser-Pereira and Gala, $2007 ; 2008$ ). If the country is able to neutralize this tendency to the overvaluation of the exchange rate by keeping control over financial flows, it will offer attractive opportunities for export oriented investments and will grow fast; if not, it will lag behind.

Globalization is a comprehensive historical phenomenon, and, therefore, a contradictory one. Some of those contradictions, such as the class struggles that characterized the first stages of capitalist development, lost their relative importance in the age of globalization; others, such as the contradiction between rich countries with expensive labor and middle-income countries with cheap labor had increased their significance. It is from this second contradiction and due to the new roles played by the nation-states in globalization that I will examine here the problem of catching up. As long as globalization implied a high increase in competition between countries or nation-states, we need to know how they compete, how they define their own national development strategies, and how this competition affects and modifies the world economic system itself. In order to discuss this issue, the approach will be economic, but it will also have to be political, since any market system, in which competitors compete regularly, is also a system of cooperation to define the rules of the competitive game.

\section{THE PRESENT STAGE OF CAPITALISM}

Globalization is, at the same time, an ongoing process of transformation the process of accelerated economic, social, and political integration the world is experiencing since the $1970 \mathrm{~s}$ - and the name of the present stage of the capitalist economic system. It is the economic system in which all the national markets become open and all the nation-states start to behave according to the logic of capitalist accumulation and competition. The dynamic nature of this stage that reflects the extraordinary speed of technological change appears in its very name, whose ending implies the idea of change. Its technological basis was the reduction in 
the costs of transportation, and, particularly, the information technology revolution, which made dramatically faster and cheaper communications and the transfer of financial assets. This technological revolution, by facilitating the creation and integration of markets at a global level, promoted on one hand an increase in international economic competition and, on the other, a reorganization of production, sponsored by multinational corporations, at unimaginable levels. As long as national economies opened up, their international competitive ability became a necessary condition for the continuity of their economic development.

In globalization nation-states remain the decisive political-territorial unity. This is clear if we consider two definitions of globalization - one strong and the other weak. According to the first one, globalization is the stage of capitalism in which economic competition for higher growth rates becomes widespread between national states. If the reader thinks this definition is strong, there is an alternative: globalization is the economic competition at world level between corporations supported by their corresponding nation-states. In both cases it is clear that the nation-state continues to play a strategic role in globalization. There is a third definition - that globalization would be the competition at world level between corporations 'without' the support of their corresponding nation-states. In fact, there are corporations, especially consulting ones that are actually multinational: Hirst and Thompson (1996) consider them as 'genuinely transnational corporations'. ${ }^{2}$ But, in the absolute majority, 'multinational' corporations are national corporations, because they are controlled by the capitals and the knowledge of one or two countries. The clearest evidence of this fact lies in the activities of the ambassadors of rich countries in developing countries. Each ambassador knows well which are 'his' corporations, i.e., which are the corporations whose interests he is supposed to represent. He knows them, and he does not hesitate in protecting their interests, since this is one of his two basic and legitimate missions (the other one is to protect his country's commercial interests). Evidently, this does not mean that I am stating that the nation-states compete internationally as the corporations do. Competition between nations has a different economic logic. The process is conducted by politicians, not by entrepreneurs. The purpose is to achieve higher growth rates rather than profit rates. The demand is not from shareholders, but from voters. On the other hand, whereas corporations are basically autonomous, nations are not, because they face the serious problem of foreign ideological hegemony. Elites in developing countries are more easily identified with rich countries' elites rather than with their own people. Now, when this happens, the classical process of association of the imperial power with the local elite takes place again.

\footnotetext{
${ }^{2}$ According to Hirst and Thompson (1996), multinational corporations are those that preserve a basis of national origin and are subject to regulation and control of the country of origin, and transnational corporations are corporations with entirely free genuine capital, without specific national identification and with an international management potentially inclined to locate and relocate anywhere in the world to obtain safer or higher returns.
} 
A fourth definition in the same line - with the difference that its origin is not neo-liberal or globalist but Marxist - is to say that the logic of capitalist accumulation became global, that capitalists have no homeland, that they invest where profit opportunities are higher, so that, once again, the nation-state would have lost autonomy and importance. This theory that was classical of international socialism has an unacceptable essentialist aspect, but we must recognize the existence of a basic ambiguity in capitalists and in enterprises. This ambiguity lies not in the fact that they look for profit wherever it could be found (this is part of the logic of market), but in the fact that, politically, capitalists actually feel as agents above the nations, and sometimes they cling to them for domestic protection or for support in their international actions. In developing countries this ambiguity is usually higher, on one hand because the national interests to which entrepreneurs are associated are smaller than in rich countries, and, on the other hand, because their societies tend to be culturally and ideologically dependent.

Global capitalism is a world economic system whose basic components are enterprises as well as the sovereign nation-states. Marx made the great analysis of capitalism on economic and social levels, but failed in the analysis of the political domain or state domain. There is no theory of the nation-state in Marx, despite the fact that the nation-state is the political and territorial unit characteristic of capitalist societies. Whereas in pre-capitalist societies the classical empires were the political and territorial unit, in capitalism it is the nation-state that takes on this role. ${ }^{3}$ Nation-states are sovereign political and territorial entities, consisting of three elements: a nation, a territory, and the state. This latter, therefore, cannot be confused with the nation nor with the nation-state (nor with the government that heads the state). Whereas the nation is a type of society, and the nation-state a political and territorial unit, the state is an institution: is the constitutional system and the organization that ensures it; it is the law and the state apparatus. ${ }^{4}$ In capitalism, nations use their state as instruments of collective action to achieve their political goals, among which is always the maintenance of their own sovereignty and economic development. As Ernest Gellner (1983) shows, the empires' aristocratic elites, when promoting their territorial expansion, had no idea of productiv-

\footnotetext{
${ }^{3}$ I use 'classical' empires in order to refer to pre-capitalist empires; during the long Capitalist Revolution there were also empires such as the English one, which, however, should not be confused with the classical empires - the last one of them being the Austro-Hungarian empire. The industrial capitalism empires of the nineteenth century, such as the English and the French ones, and even the mercantile empires of the seventeenth and eighteenth centuries, such as the Spanish and the Portuguese ones, were mixed forms between the ancient empires and the modern nation-states.

${ }^{4}$ I know that these distinctions are not always clear, and this is one of the reasons why these three words are used with different meanings. In the international relations literature, 'states' in plural is also commonly used as a synonym for nation-state. In the United States, 'nation' is commonly used also as a synonym for nation-state, instead of reserving this term for national societies. Authors rarely make the necessary clear distinction between State and nation-state.
} 
ity increase or economic development, and, therefore, kept untouched the colony's social organization and culture, confining them to collect taxes from the subjugated populations. Differently, in the nation-states, they are the result of a national social agreement turned to common political purposes. The new economic and political elites do not confine themselves to concentrate military and police power to ensure their security, but their second and central goal is the economic development that legitimates them. To do that, contrarily to what happened with classical empires, the nation-states extend public education to the whole population living in the national territory, and thus, at the same time, they assure the productivity increase or the economic development, and turn their subjects into citizens, by successively acknowledging their civil, political, and social rights. As long as markets opened, and the logic of profit, of capital accumulation, and of technical progress prevailed everywhere, new nation-states were formed.

\section{GLOBALISM}

Due to the increased interdependence between nation-states in global capitalism, it was said that nation-states were no longer sovereign; moreover, they would have lost relevance. Globalization brought with it new ideologies: neo-liberalism the ideology of self-regulating markets - and globalism - the ideology of globalization. Whereas neo-liberalism is the contemporary form of aggressive nineteenth century's laissez-faire, globalism praises globalization, states the irrelevance of the nation-state in this economic and social setting, and views globalization as an inevitable process of increasing dominance of the markets over the coordination of economic systems. Whereas neo-liberalism is an ideology for internal use, aimed at legitimating the reduction of expenditures with the assurance of social rights, globalism is mainly useful at foreign level and is focused on developing countries.

By showing to developing societies the growing lack of autonomy and significance of their nation-states, this ideology is useful for limiting nationalist manifestations in those societies and for leading their dependent elites to subordinate to rich countries' elites. The world, according to globalism, would be or would tend to be a 'borderless society' (Kenich Ohmae, 1990). Or else the borders would be losing sense as long as many sub-national problems become more relevant than the national ones (Saskia Sassen, 2005). ${ }^{5}$ This assumption may assume a deterministic nature that appears, for instance, in Octavio Ianni's (1995: 40) assertion, according to whom, due to the technological and economic changes as well as to the logic of capital accumulation, "the sovereignty of the nation-state is not just

\footnotetext{
${ }^{5}$ This author's position is contradictory, because he thinks that "globalization is partly a system located inside the national states", but that "highly specialized and therefore obscure factors denationalize specific components of the State's work" (Sassen, 2005: 524).
} 
being limited, but shaken at its base. When the principle of capital accumulation is pushed to its last consequences, it translates as an intensive and extensive development of productive forces and relations of production, at a global level".

The central idea of globalism is that, in globalization, the nation-states became more interdependent, lost autonomy to implement policies and, therefore, significance. Yet, it is easy to show the opposite starting from the same assumptions. Indeed, globalization is characterized by a greater interdependence between the nation-states, and greater interdependence means some loss of autonomy. But what is the reason for this greater interdependence? It is not the increase in cooperation, but the increase in competition between the countries - that makes states and its governments much more strategic economically than they were before globalization, when each country had to compete just with one or another, often neighbors.

Besides being a fact, interdependence is, as of the 1970s, a rhetoric or an ideology. As Keohane and Nye (2001: 6) remark, "for those who wish the United States to retain world leadership, interdependence has become part of the new rhetoric, to be used against both economic nationalism at home and assertive challenges abroad". In the 1990s, when American ideological hegemony reached its peak, the leitmotiv of President Bill Clinton's speeches was globalization and interdependence. Both would lead all countries to reduce their conflicts and to cooperate. Actually, economic competition greatly increased.

It was in the 1990s that appeared the theory of the 'global governance', whose more systematic presentation was made by David Held and Anthony McGrew (2002). According to this theory, that became popular within international organizations including the United Nations, the nation-states had ceased to have a key role since a large number of other international organizations, whether official or non-governmental, would participate in a hypothetical world government, no longer called 'government' but rather 'governance'. ${ }^{6}$ Once again, we faced a hegemonic rhetoric that makes no sense. Although the Global Political System headed by the United Nations is developing in the frame of globalization, we are still far from the moment when nation-states can retire. Ulrich Beck (1997: 1011 ) is correct when says that globalization or globality "means that we have been living for a long time in a world society". Yet, we have a global society without a global state. Thus, his conclusion makes little sense: "globalization denotes the process through which sovereign national states are criss-crossed und undermined by transnational actors with varying prospects of power, orientations, identities and networks". This is to overestimate the global civil society that is really emerg-

\footnotetext{
${ }^{6}$ Note that I am using 'government' as synonym of state as it is usual in American English, but to indicate either the group of top elected and non-elected civil servants that run the state, or the process of governing. Governance would be the governing process from which participate other groups and individuals — civil society.
} 
ing and underestimating the nation-states that were never before so strategic in the global economic competition.

The emergence of such ideas, in a moment of the history of mankind in which, after all, the surface of the earth is covered with nation-states, has one paradoxical aspect. Until World War II the world map was mainly occupied by empires, no longer the classical but the capitalist empires, particularly of Great Britain and France. Later, we saw the emergence of a growing number of nation-states, as the old colonies became independent. For some time, the constitution of the Soviet Empire implied retrogression in this process, but, with its collapse, the world capitalist society fully assumed its intrinsic character of an economic system politically and geographically organized according to nation-states. This is why José Luís Fiori (2002: 36) correctly asks: "how to explain this paradox that announces the death of the states' sovereignty as a result of globalization, exactly at the time when they are multiplying and becoming a global phenomenon?”

A second assumption of globalism is that there is only one path to economic development, and its model is the American capitalism. Therefore, the loss of autonomy of nation-states should not be deplored but welcome because this will make easier for every country to follow the same path towards development - the one presumed to be the more successful — the American model. There is, however, no reason to consider the American model of capitalism superior to the Western Europe capitalism. As there are many models or varieties of capitalism, there are also very different national strategies of economic development. The countries that have achieved the best results use very different strategies from those recommended by rich countries through their agencies.

As globalism is based on some real facts, and particularly because it is an ideology of the hegemonic center, it also attains the left-wing critics who, instead of denying globalization, deplore the alleged loss of autonomy and significance of the nation-states. ${ }^{7}$ To those two opposing groups a third one is added, formed by progressive European intellectuals, like Jürgen Habermas, which confuse the consequences of globalization with the loss of national autonomy resulting from the process of organization of the European Union. They do not realize that the European Union is not a sign of the weakening of the idea of national states, but rather an attempt at the formation of an European multinational state stronger than the individual nation-states. ${ }^{8}$

\footnotetext{
${ }^{7}$ The left wing basic book on globalization is by François Chesnais (1994). Gilberto Dupas (2006: $150)$ points out that "the globalization process has progressively constrained the power of the states". We have seen that Octavio Ianni thought likewise in his pioneer works on globalization.

${ }^{8}$ See Habermas $(1995 ;$ 2000). In this last book, a French collection of Habermas' papers with the title Après l'État Nation, in the 1998 and 2000 essays the concern with Europe is mixed up with globalization; in the 1999 essay, the attention is more turned toward extending the democratic policy to a system in which the nation-state inevitably loses autonomy. The idea that, despite the growing
} 
Today there is a large literature criticizing globalism. Robert Wade (1996), for instance, made a careful analysis of the problem and concluded, with a remark that is in the title of his chapter, that "the death of national economies was greatly exaggerated". Robert Boyer (2001: 12), summing up the conclusions of a broad study on the models of capitalism or modes of regulation, remarked that, "regarding this issue there is almost complete unanimity: each chapter develops an original argument regarding the lack of convergence of institutional reforms, even if they respond to the same imperatives".

The fact that rich countries, through their financial systems and multilateral agencies, force developing countries to adopt neo-liberal reforms by imposing 'conditionalities' would just aim at hastening an inevitable process that would take place anyway. For example, at the World Trade Organization, during the Uruguay Round that ended in the 1990s, these countries were able to substantially reduce the room for economic policy of developing countries, by making illegal a number of practices that they have themselves largely used in the past (Wade, 2003; Chang, 2006).

\section{GLOBALIZATION AND CATCHING UP}

In globalization, the international division of labor between rich and middleincome countries follows a simple rule: tasks with higher value-added per capita, which are not standardized nor codified and require more skilled labor, composed primarily of managers and communicators, would be performed in rich countries that have plenty of this kind of labor, whereas standardized or codified tasks would be transferred to low-wage workers in developing countries. This process enables developing countries to catch up profiting from their advantages of cheap labor and capacity for importing technology at a relatively low cost, and, at the same time, would guarantee that rich countries continued to grow at satisfactory rates, even if facing the problems of delocalization and de-industrialization. As long as the new tasks in the manufacturing industry and in services have a higher technological content, demanding more skilled labor compatible with a higher value-added per capita, and, therefore, with higher wages, the rich countries should continue to grow satisfactorily in the frame of globalization. Their real cost would be the greater concentration of income in the short run, since, initially, the wages of their less skilled workers would relatively decline and would only rise again if they went through a qualification process inherent to the development centered on industries with higher technological content.

Economic theory's assumption that developing countries should catch up seems confirmed. An increasingly significant group are fast growing economies,

interdependence, the nation-states should firmly defend their interests, particularly economic ones, is erroneously discarded by Habermas. 
profiting from the advantage of their lower labor cost and exporting to rich countries; those countries continue to industrialize because they are still transferring labor from agriculture and underemployment to manufacturing industry. However, not all middle-income countries have been successful in this transfer and in the catching $u p$, because not all are strong enough to face the ideological hegemony from the North. Whereas the dynamic Asian countries succeed, Latin American middle-income countries fail, with the exception of Chile and, more recently, of Argentina: they grow at lower rates than the rich countries and do not catch up. In these low growing economies, societies lacking cohesion and alienated ruling elites do not know how to use their states strategically and grow. This will depend on each country's national cohesion, and on the autonomy of its ruling elites with respect to rich countries.

Globalization is being accompanied by income concentration. Yet, the increase in inequality is not mainly a consequence of more open markets, but from the Information Technology Revolution that increased the demand for skilled labor and decreased the demand for unskilled labor, and from the neo-liberal ideology that precisely aimed such outcome. Trade opening (and immigration) causes some income concentration in rich countries since it forces local workers to compete with cheaper labor, but rich countries have means to defend themselves against it. Besides creating increasing difficulties to immigration (since there is no political globalization, there is no migratory globalization as well), they establish countervailing social measures. As John Stephens (2005) observes, the possible reductions in wages caused by the competition from middle-income countries tend to be compensated by measures increasing social protection. The Scandinavian institution of flexsecurity has this purpose. ${ }^{9}$

The assumption that globalization increases inequality within each country is being confirmed by the facts, while the assertion that it is an obstacle to developing countries fell into discredit. ${ }^{10}$ Despite the imperialist strategy implicit in the globalist attempt to neutralize national strategies, a significant number of middle-income countries, as China, India, South Korea, Taiwan, Thailand, Malaysia, and Indonesia - and more recently also Russia, Argentina, and Vietnam — are growing at substantially higher rates than the rich countries - are catching up, and, therefore, approaching the levels of income of the rich countries. Yet in other middle-income countries, particularly in Latin America, but also in the Middle East and Sub-Saharan

\footnotetext{
${ }^{9}$ For an excellent short description of flexsecurity or of 'the Copenhagen consensus', see Kuttner (2008).

${ }^{10}$ The participants of the World Social Forum, for instance, no longer define their movement as antiglobalization and now fight for 'another globalization', more equitable. Marxist analysts such as Ben Fine (2004: 212) have ceased to view globalization negatively and consider it as "a reaction, or even an absolute rejection of neo-liberalism", as long as it is not a mere ideology but capitalism materially in movement.
} 
Africa, the growth rates are being much more modest. In other words, we have fast growing and low growing developing countries. Commercial globalization implies a major opportunity for the developing countries that is being used by the nationalist and fast growing Asian countries, including two population giants, China and India, so that globalization - in global, not in national terms - is becoming a process of redistribution of income and wealth in behalf of the fast growing developing countries. As Grunberg and Laid (2007: 137) remark, "over the years, globalization will appear as it really is: a historical process of redistribution of wealth and power in behalf of world regions that were deprived from them during at least two centuries". This expression absolutely does not announce the funeral of the West, because international trade is a game whose sum is higher than zero, but it indicates that the banner of globalization carried by the United States in the 1990s is far from being favorable to rich countries as presumed. Globalization also acts in their favor since the accelerated growth of an increasingnumber of middle-income countries and the ever growing trade they are involved are factors that benefit rich countries as well. Contrarily to what a great number of people in rich countries believe, globalization does not reduce but rather increases those countries' growth rates, and, although creating new challenges, particularly to the Social State that developed in Northwestern Europe, does not destroy it (Glatzer and Rueschmeyer, 2005). What occurs is just a process of flexsecurity, by which the workers' stability in enterprises is reduced but, as a trade-off, the state's social expenditure is increased. The relations of power between rich countries and dynamic middle-income countries change in behalf of these latter, but the standards of living continue to increase in both groups of countries.

\section{COMMERCIAL AND FINANCIAL GLOBALIZATION}

The participation of all developing countries in world exports went from $20 \%$ in 1970 to $43 \%$ in 2005; and their participation in the global product in terms of purchasing power parity, which corresponded to $80 \%$ at the end of the eighteenth century, thanks mostly to China and India, was reduced to $20 \%$ in 1950 , as a consequence of the imperialism to which were submitted those two countries, but in the last 25 years it rose again and represented already $45 \%$ of world GDP in $2005 .{ }^{11}$ Globalization is, therefore, producing a reorganization of the whole world production. Rich countries, as well as a great number of developing countries, are growing at higher rates than in the past, but among them the dynamic middleincome Asian countries, Russia, and Argentina are growing faster and catching up. Asia, which for centuries was the world's richest region, regains importance in the world economy.

The accelerated economic development that we are watching in middle in-

11 The source of these data is Woodall (2006) based on OCDE data collected by Angus Maddison. 
come countries does not happen by accident. They have nationalist business and bureaucratic elites who adopt a national development strategy that I call 'new developmentalism' which, on the long term is based on growth with domestic savings and a sensible balance between market and state coordination of the economy, and, on the short term, on competent macroeconomic policies that assure control of inflation, balanced public budget, interest rates at a moderate level, and a competitive exchange rate (Bresser-Pereira, 2007; 2006b). A national development strategy is an informal agreement among social classes, under the leadership or the intermediation of the government, aiming at economic development; it is the key institution to economic development in so far as it is essentially concerned with the promotion of investment opportunities (Bresser-Pereira 2006). It presumes the existence of a developmental state - that is, a state that puts the problem of economic development as one of its central roles, as has always been the case of the American state (despite the fact that its orthodox economists insist on rejecting developmentalism). In Latin America, between the 1950s and the 1970s, when growth rates were high, the corresponding states were called 'developmentalists'. More recently, since the pioneering contribution of Chalmers Johnson regarding Japan (1982), the expression 'developmental state' has been mainly reserved, by international political economy, to define the state of the dynamic Asian countries (Evans, 1995; Woo-Cummings, ed., 1999). Is not necessary, however, that the state is referred to as developmental to have a national development strategy. Ireland, for instance, grew in the last 20 years at extraordinary rates, as a result of a national strategy (Godoi, 2007). Regarding national development strategies, we must for now just consider that they constitute an institution, or more precisely a set of laws, policies, and agreements aimed at creating lucrative investment opportunities to entrepreneurs.

Although the rich countries only realized the competition they suffer from the developing countries as of the 1970s, when the NICs (Newly Industrializing Countries) appeared, there has always been conflicting rather than cooperative relations between them. At first, it was not the financial opening but the commercial one that was ideologically used by the rich countries to limit the competitive ability of the new countries. Since the first industrial revolution took place in England, this country tried to obstruct the catching up of the other European countries. Friedrich List (1846) coined the phrase "kicking away the ladder" to illustrate this behavior; and Ha-Joon Chang (2002) gave it empirical content. Since the beginning of the nineteenth century, the countries that industrialized tried initially to neutralize the competitive ability of the countries that came behind them, arguing and pressing for open international markets. This strategy worked for a period, but in the end each country realized the need of protection to ensure its infant industry, and tried to create high customs tariffs. The United States and Germany industrialized in the nineteenth century based on this understanding. In Latin America, from the 1930s on, the region's most important countries also reached 
industrialization by protecting their infant industries. And the same occurred in Asia, soon after World War II. Therefore, although, during some time, the strategy of neutralizing competitors based on the law of comparative advantages has been effective in persuading competitors not to industrialize, it eventually became exhausted as long as middle-income countries achieved industrialization despite the neo-liberal argumentation based on the law. Trade globalization lost power as an ideological weapon. Today, protective measures emanate increasingly from rich countries, not from middle-income countries, that know how to take advantage of the opportunity represented by the trade opening.

Yet, while commercial globalization is an opportunity for developing countries, financial globalization is a threat in so far as it leads countries to lose control of their exchange rates. Financial opening is decisively favorable to rich countries, since it prevents developing countries from neutralizing the tendency to the exchange rate overvaluation. This is why, since the early 1990s, when neo-liberal hegemony seemed to be invincible, grew the pressures for developing countries to open their capital account and to try growing with the use of foreign savings. Although many are the diagnoses, recommendations, and pressures made by rich countries, through the World Bank, the IMF, and agents of the international financial system, the core of the conventional orthodoxy is currently devoted to keep the exchange rate of the developing countries relatively appreciated. This orthodoxy is not yet committed to denying the tendency to exchange rate overvaluation that I have recently identified, merely insisting on stating the unfeasibility of managing this rate. ${ }^{12}$ Conventional orthodoxy knows that only by means of an overvalued exchange rate rich countries may compensate for the advantage of middle-income countries due to their cheap labor. Therefore, it denies the existence or the relevance of the Dutch disease for developing countries, insists on proposing the growth with foreign savings policy, and claims that any intervention in the exchange rate is unfair - it is a way of growing at the neighbor's expense (of 'begging thy neighbor'). Besides, it insistently argues that the use of 'competitive devaluations' weakens technological progress and so productivity as it artificially protects business enterprises from foreign competition - despite the fact that what I am proposing is just the neutralization of the tendency to the overvaluation of the exchange rate. Its best efforts are directed to protect the growth with foreign savings policy, ignoring that current account deficit implies a high rate of substitution of foreign for domestic savings. Actually, the growth with foreign savings policy is positive to the country only in a very particular situation, when the national economy is already growing fast and the prospects of profits are very high, because at that moment the wage increases caused by the exchange rate appreciation are not mainly oriented to consumption but rather to investment. Outside this particular situation, the consequence of the exchange

\footnotetext{
${ }^{12}$ I originally discussed this thesis in Bresser-Pereira (2007; 2008).
} 
rate appreciation will be, besides a decrease in exports and an increase in imports, successively: the increase in real wages, the increase in domestic consumption, the substitution of foreign for domestic savings, the growing financial fragility accentuating dependence, and, eventually, if the country does not wake up before, the balance-of-payment crisis.

In order to successfully compete in globalization, the necessary national development strategy of the successful Asian countries was always based on a severe fiscal adjustment and a competitive exchange rate. Differently from Latin America, the land reform that strongly reduced the differences of income between households made it possible for governments not to try to counterbalance the concentration of income with social expenditure. This prevented fiscal populism. Yet, as concerns the exchange rate the dynamic Asian countries established strict limits to foreign indebtedness and limited capital inflow whenever necessary. They did not need to limit capital outflows because, except for the 1990s, when four of their countries were attracted by the growth with foreign savings policy and went through the 1997 crisis, they have always kept their foreign accounts balanced, and when they went into debt they did it moderately, to profit from a growth whose dynamics was internal.

\section{COMPARISON BETWEEN ASIAN AND LATIN-AMERICAN COUNTRIES}

The key variable that distinguishes new developmentalism from conventional orthodoxy is the exchange rate. While conventional orthodoxy rejects the administration of the exchange rate, new developmentalism requires it because knows how strategic is the exchange rate. Whereas fast growing Asian countries have new developmentalism as national strategy, low growing Latin American countries accept passively conventional orthodoxy. Whereas the former grow with domestic savings and either do not have the Dutch disease problem or neutralize it, the later still believe that they need foreign savings to finance growth, and ignore the Dutch disease..$^{13}$ Although the catching up of middle-income countries depends on other variables, it depends essentially on the country's rate of accumulation and on macroeconomic stability. Rigorous fiscal policy and a competitive exchange rate are two central conditions for such stability. A competitive exchange rate is still more important in globalization, since it is a condition for the export-led growth strategy — the one that profits from the advantage that cheap labor represents for emerging countries.

\footnotetext{
${ }^{13}$ Usually presented as a country subordinated to conventional orthodoxy, during the 1990s Chile was the only country that controlled capitals in order to prevent its exchange rate from appreciating. On the other hand, in spite of the neoliberal wave, Chile neutralized the Dutch disease caused by copper exports, on the one hand by keeping under State control an important part of its production, and, on the other hand, by establishing an export tax that prevented the local currency from overvaluing.
} 
Table 1: Growth of the average income per capita in the dynamic Asian countries and in the major Latin American Countries: 1990-2005

\begin{tabular}{cccc}
\hline $\begin{array}{c}\text { Dynamic Asian } \\
\text { Countries }\end{array}$ & $\begin{array}{c}\text { Annual } \\
\text { Growth }\end{array}$ & $\begin{array}{c}\text { Major Latin American } \\
\text { Countries }\end{array}$ & $\begin{array}{c}\text { Annual } \\
\text { Growth }\end{array}$ \\
\hline China & 11.2 & Argentina & 4.3 \\
Korea & 7.4 & Bolivia & 3.4 \\
India & 6.2 & Brazil & 2.9 \\
Indonesia & 5.5 & Chile & 6.5 \\
Malaysia & 6.1 & Colombia & 3.5 \\
Thailand & 6.4 & Guatemala & 2.8 \\
Taiwan & 7.0 & Mexico & 3.9 \\
Vietnam & 8.1 & Peru & 4.2 \\
Average rate & 7.2 & Average rate & 3.9 \\
\hline
\end{tabular}

Source: IMF, World Economic Outlook. Observation: large countries: over 10 million inhabitants. Excluding the countries specialized in oil export.

From those remarks, I finish this paper with a simple comparison of the Asian countries that adopt national development strategies with the Latin American countries that as of the late 1980s (Bolivia and Mexico) or the early 1990s (Argentina and Brazil) adopted the conventional orthodoxy. A more comprehensive ranking of the developing countries would consider, in addition to the dynamic Asian countries and the Latin American ones, the other middle-income countries that grow unsatisfactorily, and the poor or low-income countries. However, I will limit my comparison to those two groups, because there is a clear contrast between the independence of the former and the dependence of the latter. In order to test if the superior performance of the dynamic Asian countries is due to the fact that those countries have a national development strategy based on a more competitive exchange rate, on greater fiscal balance, and, consequently, on a higher rate of investment than the same variables in Latin American countries, I present a simple econometric test. I will limit my comparison to eight dynamic Asian nation-states and to the major Latin American countries ${ }^{14}$ that are listed in Table 1 with their corresponding growth rates. I will make the comparison as of 1990 - because in that year the foreign debt crisis was solved by the Brady Plan and it was also around that year that Latin American countries, weakened by the great foreign debt crisis of the 1980s, began to adopt conventional orthodoxy, whereas the dynamic Asian countries continued with their own national development strategies. ${ }^{15}$ The table shows the huge difference in growth rates of both groups of

\footnotetext{
${ }^{14}$ The criterion adopted to define the major Latin American countries was the combined occurrence of a per capita income above US\$ 3000 (according to the purchasing power parity criterion) and a population over 10 million inhabitants. Countries specialized in oil or natural gas export were excluded.

${ }^{15}$ In the 1990s, some dynamic Asian countries, specifically Korea, Indonesia, Malaysia, and Thailand, have also partially submitted to conventional orthodoxy by accepting the theory of growth with cur-
} 
countries. Comparing the simple average per capita growth of both groups $(7.2 \%$ for the dynamic Asian countries versus 3.9\% for the Latin American countries) with the average growth rate of rich OECD countries in the period, ${ }^{16} 4.3 \%$, we observe that Asian countries are catching $u p$, whereas Latin Americans are not. During that period only Chile attained good growth rates. If we consider the last five years, Argentina would also show high rates.

New developmentalism - the name of the strategy that is used today by the most successful middle-income countries - may be identified in a country if we can observe in it three economic measures reasonably easy to detect: low or no public deficit, which indicates a fiscal balance; surplus current account or a small deficit, which indicates a competitive exchange rate; and a high rate of investment as compared to the GDP - the main consequence of the other two variables and the fundamental condition for catching up. Although the three variables are important, the surplus or small current account deficit is, in my view, the most important one, because it reveals that the exchange rate is being correctly managed and that the tendency to exchange rate overvaluation is being neutralized. This is a fundamental aspect, because the exchange rate is the most strategic macroeconomic price, to the extent that it influences practically all macroeconomic aggregates. If we ask what is the 'secret' of the extraordinary growth of the dynamic Asian countries, the answer will probably lie in a growth with domestic savings policy based on a competitive exchange rate. This doesn't mean that they have rejected foreign investment, but simply that they do not incur current account deficits unless for brief periods. Foreign investments received by China, for instance, are not meant to finance the current account deficit, as it happened in Latin America, but to give access to technology and foreign markets.

Table 2: Rate of investment, public deficit, and current account deficit in two groups of countries (average rate 1990-2005)

\begin{tabular}{cccc}
\hline & $\begin{array}{c}\text { Rate of } \\
\text { Investment }\end{array}$ & $\begin{array}{c}\text { Public } \\
\text { Deficit }\end{array}$ & $\begin{array}{c}\text { Current Account } \\
\text { Balance }\end{array}$ \\
\hline Dynamic Asian Countries & 28.11 & 1.42 & 0.76 \\
\hline $\begin{array}{c}\text { Major Latin American } \\
\text { Countries }\end{array}$ & 18.32 & 1.98 & -2.72 \\
\hline
\end{tabular}

Source: IMF, World Bank, CEPAL, Asian Development Bank, and UNCTAD.

Based on the remarks above, I understand that there should be a positive correlation between, on one hand, economic growth and, on the other, low public deficit, current account surplus, and high rate of investment - and, therefore,

rent account deficits. The outcome was the 1997 financial crisis, and the prompt return of those countries to the growth with domestic savings.

${ }^{16}$ Korea, Slovakia, Hungary, Mexico, Poland, Portugal, Czech Republic, and Turkey were not included in the calculation of this average. 
that, when we compare countries and their economic performance, those three variables are a good indicator of the existence of a national development strategy. The data on Table 2 confirm this assumption in the comparison between the dynamic Asian countries and Latin American ones, by presenting for both groups their public deficit, their current account deficit, and their average rate of investment in the period 1990-2005. The predictions that the dynamic Asian countries would present a lower public deficit, surplus instead of current account deficit, and a higher rate of investment than Latin American countries, are fully confirmed: in Asian countries there is less public deficit, no current account deficit but rather a surplus, and the rate of investment is much higher. The coefficient of correlation between those three factors and the growth rates is significant and positive, and the correlation of growth with the rate of investment $(0.83)$ and with the current account balance (0.6) is more significant than with the fiscal result of the public sector $(0.18) .{ }^{17}$

In order to reinforce this argument, I performed an econometric test in which I defined the GDP per capita as the dependent variable (in PPP-adjusted US\$), and as explanatory variables the current account balance, the fiscal result of the public sector (therefore, positive indicates a surplus), and the rate of investment (those three calculated in relation to GDP). The data were organized in a panel of 16 countries (those included in Table 1) which covers the period between 1990 and 2005. A regression was initially conducted in a panel with fixed effects, whose tests pointed to the occurrence of autocorrelation and heteroskedasticity between the series. Therefore, I decided to carry out a regression from a first-difference equation of those variables and from the use of heteroskedasticity-robust standard errors. ${ }^{18}$ The equation used in the test and the econometric results can be found in the Appendix of this paper.

The coefficients and the (robust) standard errors indicate that the three variables are significant to explain the behavior of the GDP per capita. As regards the public deficit and the current account deficit, the coefficient is $10 \%$, as compared to the rate of investment, $5 \%$. The three coefficients are positive, confirming the role of those variables in an economy's higher or lower GDP per capita growth rate. ${ }^{19}$

Those three variables are associated with a strong, not indebted State, that works as an instrument of collective action for the nation, and, therefore, as an

\footnotetext{
${ }^{17}$ The correlation between the average values (of said variables) in the various countries was calculated during the period under consideration (1990 to 2005). Instead of the public deficit, it wasused the public sector result, and therefore, in this case, the positive correlation occurs between the public sector surplus and the GDP per capita.

${ }^{18}$ Regression includes generalized least squares estimators.

${ }^{19}$ It is also worth mentioning that, since the variables related to the current account balance and to the rate of investment are out of pace by one period, their impact on the GDP per capita occurs from one period to the other, whereas the impact of the public deficit occurs in the period itself.
} 
instrument of the national development strategy. They are also connected to a growth with foreign savings policy that, combined with the policy aimed at neutralizing the tendency to exchange rate overvaluation, ensures lucrative investment opportunities on the demand side. Usually, the papers and studies on economic development privilege the supply side, focusing their attention on the development of human capital, technology, and economic infrastructure. Without denying the significance of this issue, the assumption in my analysis is that developing countries have abundant human and capital resources that are idle or poorly used due to the chronically overvalued exchange rate. The success of the dynamic Asian countries is partly due to the fact that they always keep control of their exchange rate, preventing it from appreciating, and, therefore, ensuring the existence of good investment opportunities for entrepreneurs and the full employment of the factors.

\section{REFERENCES}

Beck, Ulrich (1997 [2000]) What is Globalization? Cambridge: Polity Press, 2000 (Original German edition, 1997).

Boyer, Robert (2001) “Comprendre un changement d'époque”. In Robert Boyer e Pierre-François Souyri, eds. (2001): 7-22.

Boyer, Robert and Pierre-François Souyri, eds. (2001) Mondialisation et Régulations. Paris: La Découverte.

Bresser-Pereira, Luiz Carlos (2006a) "Estratégia nacional de desenvolvimento". Revista de Economia Política 26 (2): 203-230.

Bresser-Pereira, Luiz Carlos (2006b) "New developmentalism and conventional orthodoxy". Economie Appliquée 59(3): 61-94.

Bresser-Pereira, Luiz Carlos (2007) Macroeconomia da Estagnação. São Paulo: Editora 34.

Bresser-Pereira, Luiz Carlos (2008) "Dutch disease and its neutralization: a Ricardian approach". Brazilian Journal of Political Economy 28 (1): 47-71.

Bresser-Pereira, Luiz Carlos and Paulo Gala (2008) "Foreign savings, insufficiency of demand, and low growth". Journal of Post Keynesian Economics 30 (3): 315-334.

Bresser-Pereira, Luiz Carlos and Paulo Gala (2007) "Por que a poupança externa não promove o crescimento" [Why foreign savings fail to cause growth]. Revista de Economia Politica 27 (1): 3-19. English version available at www.bresserpereira.org.br.

Bresser-Pereira, Luiz Carlos and Yoshiaki Nakano (2002) "Economic growth with foreign savings?" Paper presented at the Seventh International Post Keynesian Workshop, Kansas City, Mi., June 28-July 3 2002. Available in the original at www.bresserpereira.org.br, and, in Portuguese, Revista de Economia Política 22(2) April 2003: 3-27.

Chang, Ha-Joon (2002) Kicking Away the Ladder. London: Anthem Press.

Chang, Ha-Joon (2006) "Policy space in historical perspective, with a special reference to trade and industrial policies". Economic and Political Weekly, 41 (7): 627-633.

Chesnais, François (1994) La Mondialisation du Capital. Paris: Syros.

Dupas, Gilberto (2006) O Mito do Progresso [The Myth of Progress]. São Paulo: Editora Unesp.

Evans, Peter (1995) Embedded Autonomy. Princeton, NJ: Princeton University Press.

Fine, Ben (2003) “New growth theory”. In Ha-Joon Chang, ed. (2003) Rethinking Development Economics. London: Anthem Press: 201-217.

Gellner, Ernest (1983) Nations and Nationalism. Ithaca: Cornell University Press. 
Glatzer, Miguel and Dietrich Rueschmeyer (2005) "Introduction to the problem" and "Conclusion: policy matters”, in Miguel Glatzer and Dietrich Rueschmeyer, orgs. (2005): 1-22 e 203-225.

Glatzer, Miguel and Dietrich Rueschmeyer, eds. (2005) Globalization and the Future of the Welfare State. Pittsburgh: University of Pittsburgh Press.

Godoi, Alexandra Strommer de Farias (2006) “O milagre irlandês como exemplo da adoção de uma estratégia nacional de desenvolvimento" [The Irish miracle as an example of the adoption of a national development strategy]. Revista de Economia Política 27 (4): 546-566.

Grunberg, Gerard and Zali Laïd (2007) Sortir du Pessimisme Social. Paris: Hachette and Science Po.

Habermas, Jürgen (1995) “O Estado-Nação Europeu frente aos Desafios da Globalização" [The European Nation-State and the Challenges of Globalization]. Novos Estudos Cebrap, ${ }^{\circ} 43$ november 1996.

Habermas, Jurgen (2000) Après l'État-nation. Paris: Fayard.

Held, David and Anthony McGrew (2002) "Introduction". In Held and McGrew, eds. (2002). 1-25.

Held, David and Anthony McGrew, eds. (2002) Governing Globalization. Cambridge: Polity Press.

Hirst, Paul and Grahame Thompson (1996) Globalization in Question. Cambridge: Polity Press.

Ianni, Octavio (1995) Teorias da Globalização [Theories of Globalizaion]. Rio de Janeiro: Civilização Brasileira.

Johnson, Chalmers (1982) MITI and the Japanese Miracle. Stanford: Stanford University Press.

Keohane, Robert O. and Joseph S. Nye (2001) Power and Interdependence. $3^{\text {rd }}$ edition. New York: Longman.

Kuttner, Robert (2008) “The Copenhagen consensus”. Foreign Affairs, March-April: 78-94.

List, Friedrich (1846 [1999]) National System of Political Economy. Roseville, CA: Dry Bones Press, 1999.

Ohmae, Kenich (1990) The Borderless World. New York: HarperCollins Publishers.

Sassen, Saskia (2005) "When national territory is home to the global: old borders to novel borderings". New Political Economy 10 (4): 523-542.

Stephens, John D. (2005) “Economic internationalization and domestic compensation”. In Glatzer and Rueschmeyer, eds. (2005): 49-74.

Wade, Robert (1996) "Globalization and its limits: reports of the death of the national economy are greatly exaggerated”. In S. Berger and R. Dore, eds. (1996) National Diversity \& Global Capitalism. Ithaca: Cornell University Press: 60-88.

Wade, Robert H. (2003) "What strategies are viable for developing countries today? The World Trade Organization and the shrinking of 'developent space'". Review of International Political Economy 10(4): 621-644.

Wolf, Martin (2004) Why Globalization Works. New Haven: Yale University Press.

Woo-Cumings, Meredith, ed. (1999) The Developmental State. Ithaca: Cornell University Press.

Woodall, Pan (2006) "The new titans". The Economist, September 14, 2006.

World Bank (2002) Globalization, Growth, and Poverty. Washington and Oxford: World Bank and Oxford University Press.

\section{APPENDIX}

\section{Equation}

d.PIBk $k_{i, t}=\beta_{0}+\beta_{1} d$. Defpub $_{i, t}+\beta_{2}$ ldInvest $_{i, t}+\beta_{3}$ ld Contcorr $_{i, t}+\varepsilon_{i, t}$ where: $d . P I B k=$ GDP per capita (first difference), $d . D e f p u b=$ Public sector result / GDP (first difference), ldInvest $=$ Rate of investment (gross formation of fixed capital / GDP — first difference out of pace by one period), ldContacorr $=$ Current account balance / GDP (first difference out of pace by one period), $i=$ country, and $t=$ period. 


\section{Results of the panel analysis}

\begin{tabular}{|c|c|c|c|c|c|c|}
\hline Random-effects & s GLS regressic & & Number of & & 224 & \\
\hline Group variable & (i): paisnum & & Number of & groups & 16 & \\
\hline $\begin{aligned} \text { R-sq: } & \text { within } \\
& \text { between } \\
& \text { overall }\end{aligned}$ & $\begin{array}{l}=0.0738 \\
=0.0137 \\
=0.0301\end{array}$ & & Obs per gro & $\begin{array}{r}\text { up: } \min \\
\text { avg } \\
\max \end{array}$ & $\begin{array}{r}14 \\
14.0 \\
14\end{array}$ & \\
\hline $\begin{array}{l}\text { Random effects } \\
\operatorname{corr}\left(\mathrm{u} \_\mathrm{i}, \mathrm{X}\right)\end{array}$ & $\begin{array}{l}\text { s u_i } \sim \text { Gaussia } \\
=0 \text { (assumed }\end{array}$ & & $\begin{array}{l}\text { Wald chi2 } 4 \\
\text { Prob }>\text { chi } 2\end{array}$ & & $\begin{array}{r}=38.37 \\
=0.0000\end{array}$ & \\
\hline D.pibk | & Coef. & $\begin{array}{l}\text { Robust } \\
\text { Std. Err. }\end{array}$ & $\mathrm{z}$ & $\mathrm{P}>|\mathrm{z}|$ & {$[95 \% \mathrm{C}$} & Interval] \\
\hline D.defpub | & 36.86118 & 19.69917 & 1.87 & 0.06 & -1.748483 & 75.47085 \\
\hline ldinvest I & 36.57935 & 15.33271 & 2.39 & 0.02 & 6.527793 & 66.63091 \\
\hline ldcontcorr I & 20.08072 & 12.30499 & 1.63 & 0.10 & -4.036613 & 44.19805 \\
\hline _con I & 354.9966 & 74.5847 & 4.76 & 0.00 & 208.8133 & 501.18 \\
\hline
\end{tabular}

